\title{
Severe coral bleaching of Siderastrea stellata at the only atoll in the South Atlantic driven by sequential Marine Heatwaves
}

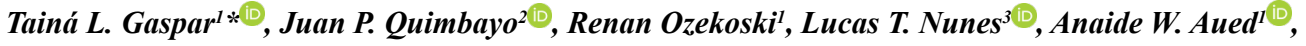 \\ Thiago C. Mendes ${ }^{\circledR}$, Amana G. Garrido ${ }^{5}$, Bárbara Segal ${ }^{1,6}$ \\ ${ }^{1}$ Universidade Federal de Santa Catarina, Departamento de Ecologia e Zoologia, Laboratório de Ecologia de \\ Ambientes Recifais, 88010-970, Florianópolis, SC, Brasil. \\ ${ }^{2}$ Universidade de São Paulo, Centro de Biologia Marinha, 11612-109, São Sebastião, SP, Brasil. \\ ${ }^{3}$ Universidade Federal de Santa Catarina, Laboratório de Macroecologia e Biogeografia Marinha, 88010-970, \\ Florianópolis, SC, Brasil. \\ ${ }^{4}$ Universidade Federal de São Paulo, Instituto do Mar, 11070-100, Santos, SP, Brasil. \\ ${ }^{5}$ Universidade Federal do Rio de Janeiro, Programa de Pós-Graduação em Biodiversidade e Biologia \\ Evolutiva, 21641-902, Rio de Janeiro, RJ, Brasil. \\ ${ }^{6}$ Instituto Coral Vivo, Estrada da Balsa Km 4,5, Praia do Araçaípe, Arraial d'Ajuda Eco Parque, Arraial \\ d'Ajuda, 45816-000, Porto Seguro, BA, Brasil. \\ *Corresponding author:Tainá L. Gasparautor,e-mail: tainalgaspar@gmail.com
}

GASPAR, T.L., QUIMBAYO, J.P., OZEKOSKI, R., NUNES, L.T., AUED, A.W., MENDES, T.C., GARRIDO, A.G., SEGAL, B. Severe coral bleaching of Siderastrea stellata at the only atoll in the South Atlantic driven by sequential Marine Heatwaves. Biota Neotropica 21(2): e20201131 https://doi.org/10.1590/1676-0611-BN-2020-1131

\begin{abstract}
Threatened by global warming and extreme climatic events, such as El Niño Southern Oscillation (ENSO) and Marine Heatwaves (MHW), coral reefs worldwide faced the worst bleaching and mortality event between 2014 and 2017, induced by the 2015/2016 ENSO. We evaluated the impacts of ENSO and MHW episodes on bleaching and mortality frequencies of Siderastrea stellata at Rocas Atoll, Southwestern Atlantic, using visual censuses conducted in 2016, 2017 and 2019. Bleaching rate varied significantly along the sampling period $(11.71 \%$ in $2016,1.52 \%$ in 2017 , and $88 \%$ in 2019), but mortality was always less than $4 \%$. Bleaching events in Atlantic reefs have been constantly associated with ENSO, until these recent events of the last two years. We suggest that MHW were probably the primary driver of the observed bleaching, especially in 2019, when much higher bleaching rates were observed than in ENSO periods. Although Southwestern Atlantic massive corals are considered more resistant to thermal stress than reefs corals worldwide, the strong events registered since 2019 highlight the need for continuous monitoring to better understand coral bleaching dynamics and improve predictions on the effects of global change in the region.

Keywords: Climate change; coral mortality; El Niño Southern Oscillation (ENSO); Brazilian reefs; Rocas Atoll.

\section{Branqueamento severo de Siderastrea stellata no único atol do Atlântico Sul impulsionado por ondas de calor marinhas sequenciais}

Resumo: Ameaçados pelo aquecimento global e eventos climáticos extremos, como El Niño Oscilação Sul (ENSO) e Ondas de Calor Marinhas (MHW), os recifes de coral em todo o mundo enfrentaram o pior evento de branqueamento e mortalidade entre 2014 e 2017, induzido pelo ENSO 2015/2016. Nesse estudo, avaliamos os impactos dos episódios de ENSO e MHW nas frequências de branqueamento e mortalidade de Siderastrea stellata no Atol de Rocas, Atlântico Sudoeste, a partir de censos visuais realizados em 2016, 2017 e 2019. O branqueamento variou significativamente ao longo do período de amostragem (11,71\% em 2016, 1,52\% em 2017, e 88\% em 2019), mas a mortalidade não, sendo sempre inferior a 4\%. Eventos de branqueamento em recifes do Atlântico têm sido constantemente associados ao ENSO, até os eventos recentes dos últimos dois anos. Nós sugerimos que as MHW foram provavelmente o principal impulsionador do branqueamento observado, especialmente em 2019, quando as taxas de branqueamento observadas foram maiores do que nos períodos de ENSO. Embora os corais massivos do Atlântico Sudoeste sejam considerados mais resistentes ao estresse térmico quando comparados com corais recifais de outros oceanos, os fortes eventos registrados desde 2019 destacam a necessidade de monitoramento contínuo para entender melhor a dinâmica do branqueamento de corais e melhorar as previsões sobre os efeitos das mudanças globais na região.

Palavras-chave: Mudanças climáticas; Mortalidade de corais; El Niño (ENSO); Recifes brasileiros; Atol das Rocas. 


\section{Introduction}

Coral reefs are among the most diverse and economically important environments on the planet, as they harbor most of the marine biodiversity and provide a large number of ecosystem services (Graham $\&$ Nash 2013). Consequently, these systems face a number of local and global anthropogenic impacts, such as overfishing, pollution, habitat destruction, introduction of exotic species, and ocean acidification (Hughes et al. 2003). However, global warming is undisputedly the biggest threat to coral reefs worldwide, especially taking into account that global climate models predict an average increase in sea surface temperature (SST) of $0.027^{\circ} \mathrm{C}$ per year from 1990 to 2090 (Bopp et al. 2013). The major negative effect caused by the increase in SST on coral reefs is the disruption of the symbiotic relationships between corals and dinoflagellates of the family Symbiodiniaceae, in a phenomenon known as "coral bleaching" (Glynn 1993). In this relationship, microalgae can provide most of the energy requirements of the coral host (Muscatine et al. 1984), and its disruption damages the physiology and energy budget of the coral (Lesser 2011). If prolonged, this disruption may lead to high levels of coral mortality (Berkelmans et al. 2004, Oliver et al. 2009, Eakin et al. 2019). Since the twentieth century, coral bleaching has been reported in scattered localities and was related to small-scale stressors such as sedimentation, freshwater supply, and colder or hotter than normal weather (Vaughan 1914, Glynn 1993, Hughes et al. 2003). However, after the 1980 s coral bleaching became more frequent worldwide (Hughes et al. 2017), with three major global scale coral bleaching events: 1997-1998, 2010 and 2014-2017 (Eakin et al. 2019).

The average annual global temperatures of the ocean and atmosphere of 2015, 2016, and 2017 were the highest ever recorded since the $1800 \mathrm{~s}$ (Hughes et al. 2017). During 2015/2016 a strong and prolonged ENSO (El Niño Southern Oscillation) raised the global mean SST by $0.5^{\circ} \mathrm{C}$, and remarkably, 2017 was the warmest non-El Niño year ever registered (Eakin et al. 2019). This severe warm period sparked the most intense massive bleaching of corals worldwide and became known as the third global coral bleaching event (GCBE) (Hughes et al. 2018, Eakin et al. 2019). During this event, the highest incidence of coral bleaching and mortality in the Atlantic was recorded in the Caribbean (Hughes et al. 2017). In Brazil, some reefs showed up to $73 \%$ bleaching for some coral species, but mortality was overall lower than 3\% (Teixeira et al. 2019). In addition, Southwestern Atlantic reefs faced a record-breaking heatwave event in 2019, which, together with the ENSO positive phase, increased SST and triggered mass coral bleaching (Banha et al. 2019, Duarte et al. 2020). These bleaching episodes have been reported in the Southwestern Atlantic reefs since 1993 (Migotto 1997), but while most of them have been related to ENSO (Kelmo \& Atrill 2013, Ferreira et al. 2013, Miranda et al. 2013, Dias \& Gondim 2016, Leão et al. 2016, Lisboa et al. 2018), there is still no consensus about the main drivers generating recent thermal anomalies that trigger coral bleaching in the region (Soares et. al. 2019).

Besides ENSO, another climatic factor that has impacted the Brazilian marine ecosystem are the Marine Heatwaves - MHW (Rodrigues et al. 2019), which probability of occurrence has already increased more than 20 times due to global warming (Laufkötter et al. 2020). Defined as a period of at least five days wherein the temperature is above the $90^{\text {th }}$ percentile of the values historically observed for a given location and at a certain time of the year, the MHW are extreme climatic events in oceanic systems (Hobday et al. 2016). The impacts of MHW on marine ecosystems reported so far include, for example, mass mortality of seabirds in the Northeast Pacific (Jones et al. 2018), biomass decrease, and shifts in the distribution of fish stocks (Cheung \& Frölicher 2020). However, the relationship between MHW and coral bleaching has been only recently reported (Fordyce et al. 2019, Smale et al. 2019), with MHW promoting immediate mortality and microbial biofilm formation over dead coral skeletons (Leggat et al. 2019). In view of all the impacts to coral reefs, studies that evaluate the effects of thermal anomalies on coral communities, whether by ENSO or MHW, are key to understand the dynamics of coral bleaching and to predict these impacts (Hughes et al. 2017). This is especially critical in the Southwestern Atlantic, where bleaching studies are still scarce, endemism in reef corals is high (Leão et al. 2016) and unprecedented thermal stresses have been reported (Rodrigues et al. 2019). Thus, we assessed the frequency of bleaching and mortality of the coral Siderastrea stellata Verrill, 1868 at the Rocas Atoll from 2016 to 2019, and evaluated its relation with the 2015/2016 ENSO and other climatic events, such as MHW. Rocas is potentially one of the most "pristine" areas of the Southwest Atlantic, and figures as a natural laboratory to understand the effect of thermal stress on corals, since it is not directly exposed to other anthropogenic impacts, such as pollution, urbanization and fishing (Longo et al. 2015).

\section{Material and Methods}

\section{Study area}

Located $230 \mathrm{~km}$ off the northeastern coast of Brazil, Rocas Atoll $\left(03^{\circ} 50^{\prime} \mathrm{S}, 33^{\circ} 49^{\prime} \mathrm{W}\right.$, Figure 1a) is the only atoll in the South Atlantic, and is the first no-entry marine protected area in Brazil, created in 1979. The biological reserve encompasses about $360 \mathrm{~km}^{2}$ of strictly protected area managed for research, where fishing activities and tourism are not allowed, leading to low human impact (Kikuchi \& Leão 1997, Soares 2018). The reef substrate is mainly formed by coralline algae, vermetid gastropods and encrusting foraminifera (Kikuchi \& Leão 1997), but seven species of scleractinian corals and one hydrocoral occur there (Leão et al. 2016). The atoll is subjected to intense wave action in comparison to coastal systems and is characterized by a semi-diurnal and mesotidal regime (Kikuchi \& Leão 1997). During the low tide, two main habitats can be distinguished, open pools that constantly communicate with the exterior of the atoll and are more exposed to wave action than closed pools, which remain completely isolated from the exterior area of the atoll during low tides (Figure 1b). The benthic community in Rocas is dominated by the abundant reef-building coral Siderastrea stellata (Echeverria et al. 1997, Longo et al. 2015). This species is highly tolerant to thermal stress and widely distributed and common on Brazilian coastal reefs (Leão et al. 2016, Garcia et al. 2017).

\section{Data collection}

We conducted the sampling in four tide pools (Cemitério, Tartarugas, Âncoras and Falsa Barreta; Figure 1b) during low tides in May 2016 and 2017, and in June 2019. In each pool, we performed five visual censuses along $20 \times 1 \mathrm{~m}\left(20 \mathrm{~m}^{2}\right)$ belt transects, at depths up to $5 \mathrm{~m}$, to estimate the frequency of bleaching and dead corals, according to ReBentos Protocol (Leão et al. 2015). All colonies of $S$. stellata with more than $3 \mathrm{~cm}$ in diameter within the transect area were visually counted $(\mathrm{Nmin}=1533 ; \mathrm{Nmax}=1791)$ and classified into three categories: (1) no bleaching = with no sign of affected color, (2) bleached 


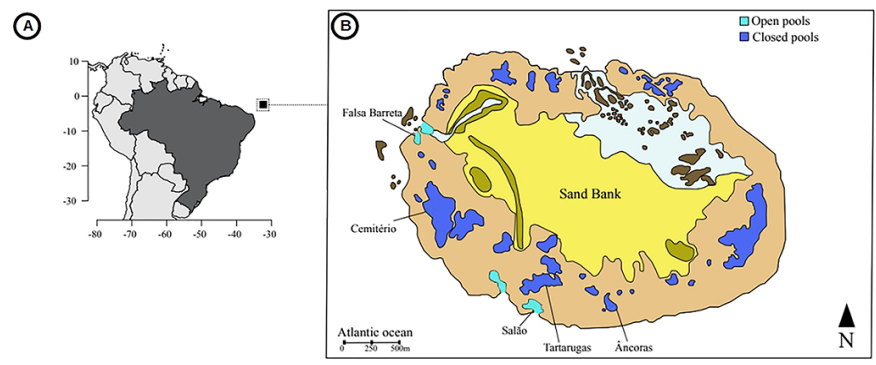

Figure 1. A) Geographic location of the Rocas Atoll and B) Position of study sites, at the tide pools: Falsa Barreta, Cemitério, Salão, Tartarugas, and Âncoras. Adapted from Longo et al. (2015)

$=$ lighter in color than normal, with different degrees of discoloration, including patches of bleaching and whiteness, and (3) recently dead $=$ bare skeleton without living tissue and minimal algal overgrowth.

\section{Abiotic factors}

To examine the effect of thermal stress events on S. stellata bleaching and mortality, we compiled a set of ocean temperature data during the sampling period at Rocas Atoll, and analyzed the coral's response considering these thermal stresses in the four months prior to the surveys. This 4 month-period was previously indicated as the time of response seen in Rocas Atoll corals (Ferreira et al. 2013). We collected the daily mean SST between 2016 and 2019 from the US National Oceanic and Atmospheric Administration Advanced Very High Resolution Radiometer (NOAA-AVHRR) (http://www. esrl.noaa.gov/psd/). Then, we obtained the Monthly Multivariate ENSO Index (MEI) values (Wolter \& Timlin 1993) from NOAA's Earth System Research Laboratory (esrl.noaa.gov/psd/enso/mei) from January 2015 to December 2019 to evaluate the effect of ENSO phases on the bleaching observed at Rocas Atoll. Considering the SST and MHW, we built an event curve between 2016 and 2019 with the Marine Heatwave Tracker, which uses the daily Optimally Interpolated Sea Surface Temperature (OISST) from the NOAA, available at $h t t p: / / w w w . m a r i n e h e a t w a v e s . o r g / t r a c k e r . h t m l,(S c h l e g e l ~ 2018)$. To assess cumulative intensity, we obtained the maximum degree heating week (DHW) value during each time interval of 4 months before sampling, from NOAACoral Reef Watch (CRW's), available at https://coralreefwatch. noaa.gov/product/vs/gauges/fernando_de_noronha.php. These values, based on CRW's Regional Virtual Station time series data, reflect the observed and forecasted bleaching alert level surrounding Rocas Atoll.

\section{Data analysis}

To examine whether the bleaching and mortality frequencies varied among 2016, 2017 and 2019, we performed two Kruskal-Wallis tests. We transformed the bleaching and mortality frequencies using the arcsine square root transformation before the analyses. We used this approach because bleaching and mortality data are percentages with a non-normal distribution, thus precluding the use of parametric tests. Additionally, we used Dunn tests for testing the difference observed in Kruskal-Wallis tests. All the analyses were performed with the R software (R Core Team 2018).

\section{Results and Discussion}

We observed a significant difference in the bleaching frequency among years (Kruskal-Wallis test: $\mathrm{X}^{2}=47.7, \mathrm{df}=2$, p-value $<0.01$ ), in contrast to the mortality frequency (Kruskal-Wallis test: $\mathrm{X}^{2}=0.51$, $\mathrm{df}=2$, p-value $=0.77$; Figure 2 ). During all sampled years, bleaching episodes were underway, which may underestimate mortality. In 2016 , average bleaching $(11.71 \% \pm$ SD 13.81$)$ and mortality $(0.97 \% \pm$ SD 2.39) frequencies at Rocas Atoll (Figure $2 b$ and $2 c$, respectively) were small compared to the severe global trend observed during the 2015/2016 ENSO (Hughes et al. 2017). This pattern was also observed in another less abundant coral species (e.g. Favia gravida, Montastraea cavernosa and Porites astreoides, ), which presented few signs of bleaching during this year (authors pers. obs.). In 2017, average bleaching frequency $(1.52 \% \pm \mathrm{SD} 1.89)$ was almost eight times smaller than 2016 (Dunn test: $z=2.30$, p-value $<0.01$; Figure $2 b$ ), but the frequency of dead colonies was three times higher (3.2\% \pm SD 6.6), despite no significant difference (Figure 2c).

Average bleaching frequency in 2019 was $88.01 \%$ ( \pm SD 8.97$)$, almost sixty times higher than 2016 (Dunn test: $z=-4.68$, p-value $<0.01$ ) and 2017 (Dunn test: $z=-6.82$, p-value $<0.01$ ) (Figure 2b). Unlike the upward trend in bleaching frequency, the number of dead colonies has halved $(1.31 \% \pm$ SD 4.12) when comparing 2017 to 2019, despite the lack of statistically significant difference (Figure 2c). Although 2019 was a non-El Niño year, the most severe bleaching event to date at the Southwestern Atlantic was recorded at that time, with high bleaching but low coral mortality (Banha et al. 2019, Duarte et al. 2020, Mies et al. 2020), similar to Rocas Atoll. The bleaching history at Rocas Atoll coincides with the ENSO years, such as the 2003 event that caused bleaching in less than $4 \%$ of the colonies studied by Ferreira et al. 2006, while during ENSO 2010, less than $20 \%$ of the colonies bleached, but up to $60 \%$ showed signs of disease (Ferreira et al. 2013).

In 2016, thermal stress events in the four months preceding the survey reached a maximum SST of $29.5^{\circ} \mathrm{C}$ and a high frequency of positive thermal anomalies that did not exceed $1{ }^{\circ} \mathrm{C}$ (Figure 3a), with a maximum DHW value less than $1{ }^{\circ} \mathrm{C}$-week. In the same period, there were three moderate MHW (Figure 3b) with an average duration of 6.6 days and average intensities, maximum and cumulative averages of $0.85^{\circ} \mathrm{C}, 1.06$ ${ }^{\circ} \mathrm{C}$ and $5.67^{\circ} \mathrm{C}$, respectively. Therefore, coral bleaching at Rocas Atoll in 2016 may not have been triggered only by ENSO (Figure 3c), but also by MHW that occurred before the sampling period. Soares et al. (2019) highlighted a bleaching event in the Southwestern Atlantic triggered by anomalous SST in 2010 that was not correlated with the ENSO, but with lower wind speeds and water turbidity.

In 2017, the daily average SST during the four months prior to the survey was similar to that observed in 2016, with maximum DHW value less than $1{ }^{\circ} \mathrm{C}$-week, and a maximum SST of $29.5^{\circ} \mathrm{C}$ (Figure $3 a)$, characterizing a hot year even without ENSO (Figure 3c). However, during this period a lower frequency of positive thermal anomalies was observed, with two episodes reaching $1^{\circ} \mathrm{C}$ (Figure 3a). Two moderate MHW occurred before sampling in 2017, with an average duration of 12 days, mean accumulated intensity of $10.57^{\circ} \mathrm{C}$, average intensity of $0.89^{\circ} \mathrm{C}$, and maximum average of $1.04^{\circ} \mathrm{C}$. The $\mathrm{MHW}$ events during the pre-sampling period in 2017 were less frequent and more interspaced, despite being longer, than the pre-sampling period in 2016 (Figure 3b), which may have influenced the low bleaching frequency in 2017.

In 2019, SST reached a maximum of $30.0^{\circ} \mathrm{C}$, and presented higher frequency and intensity $\left(1.5^{\circ} \mathrm{C}\right)$ of positive anomalies than in 2016 , with more thermal anomalies than 2017 (Figure 3a). The maximum DHW value in the period was higher than previous years, reaching $7.5^{\circ} \mathrm{C}$-week. Two MHW were registered in 2019, with an average duration of 31.5 days and 
Gaspar, T.L. et al.
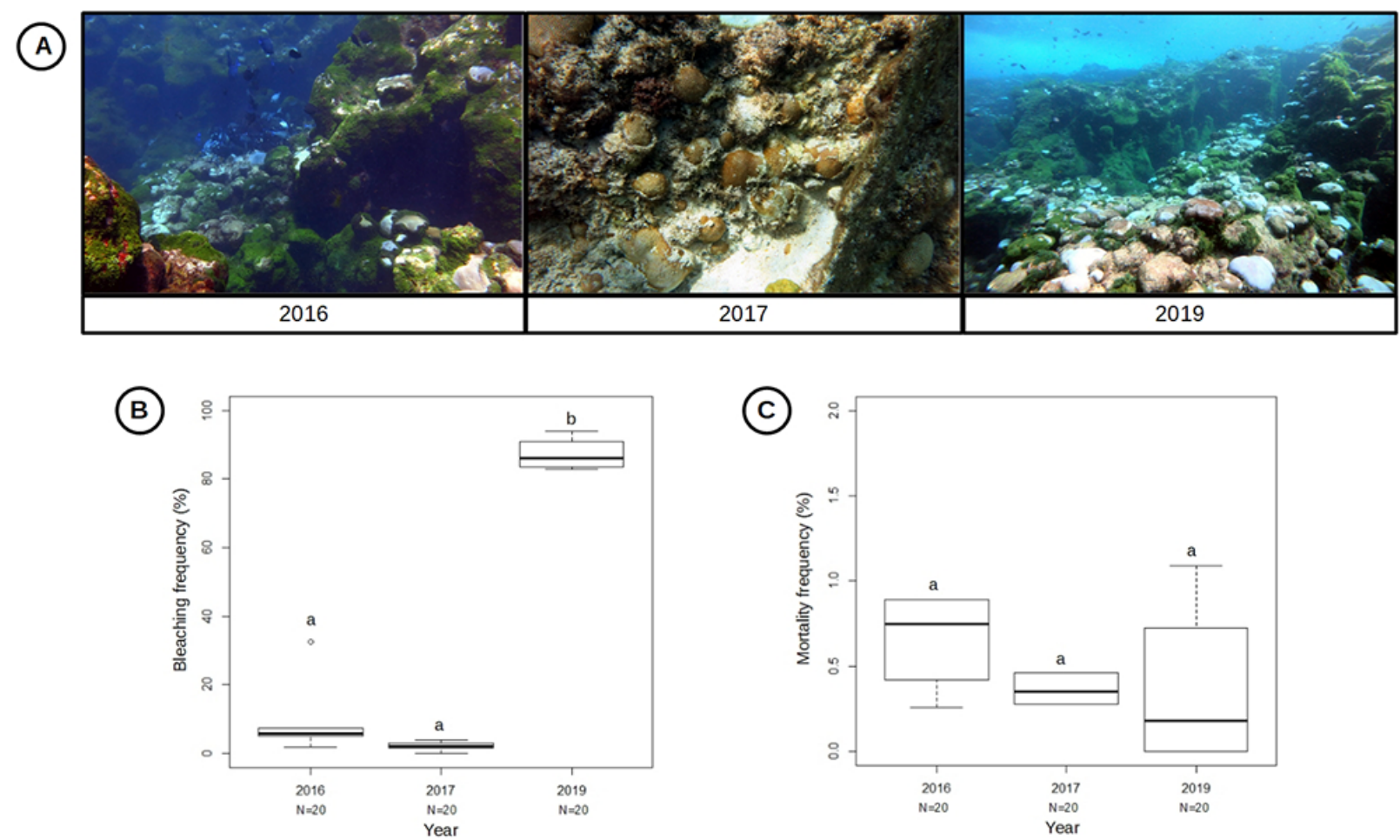

Figure 2. A) Coral communities at Rocas Atoll over sampling period (2016, 2017 and 2019), at the sampled areas. Note a few bleaching colonies of Siderastrea stellata in 2016, and several bleached colonies in 2019, while 2017, colonies were mostly healthy. B) Bleaching frequency of Siderastrea stellata at Rocas Atoll, as a function of sampling years: 2016, 2017 and 2019. Box plot center $=$ median, outerlimit $=75 \%$ percentile, and range is shown by the whiskers. In each case, data from N=20 belt transects are shown. C) Mortality frequency of Siderastrea stellata at Rocas Atoll, as a function of sampling years: 2016, 2017 and 2019. Box plot center $=$ median, outerlimit $=75 \%$ percentile, and range is shown by the whiskers. In each case, data from $\mathrm{N}=20$ belt transects are shown

a cumulative intensity of $31.51^{\circ} \mathrm{C}$, both three times higher than in previous years (Figure $3 \mathrm{~b}$ ). The intensity and maximum averages of MHW were similar to those of previous years: $1.02^{\circ} \mathrm{C}$ and $1.46^{\circ} \mathrm{C}$, respectively. Amuch lower ENSO index was detected in 2019 compared to 2016 (Figure 3c). Regarding the three sampling years, 2019 reached the highest SST, presented larger and more frequent thermal anomalies, as well as more intense MHW, which may explain the severe bleaching frequency (i.e. $>50 \%$ of bleached colonies, according to Donner et al. 2017) in 2019 (Figure 2a and 2b).

Bleaching events may have distinct outcomes, from full recovery to mass mortality, depending on the intensity and duration of the environmental stress (Glynn 1996, Baker et al. 2008), as well as the overall health state of the ecosystem (Hoegh-Guldberg 1999). Thermal stress in the South Atlantic has historically been lower than in other regions such as the Caribbean and the Indo-Pacific (Skirving et al. 2019), and its reefs have escaped multiple thermal stress events which have plagued reefs elsewhere. Despite the massive coral loss observed around the world, Southwestern Atlantic reefs have remained relatively stable in terms of mortality (Perry et al. 2013, Banha et al. 2019, Teixeira et al. 2019). Between 2014 and 2017, when the most severe, widespread, and longest-lasting global-scale coral bleaching event was recorded (Eakin et al. 2017, 2019), Abrolhos reef, in Brazil, suffered less than 3\% of coral cover loss due to bleaching and mortality (Teixeira et al. 2019).

Coral species from the Southwestern Atlantic, including S. stellata, have been considered highly resistant to thermal stress, which is possibly related to associations with thermotolerant endosymbionts (Marshall \&
Baird 2000, Loya et al. 2001, Costa et al. 2004, 2008). Colonies of S. stellata from the Northeastern Brazilian reefs harbors mainly symbionts from the genus Cladocopium (Costa et al. 2008, Monteiro et al. 2013), a genus whose lineages most frequently found on corals are thermotolerant (Swain et al. 2017). Coral colony morphology is also often related to bleaching susceptibility, with massive forms less susceptible to bleaching (Brown et al. 1990, Gleason 1993). Most Brazilian coral species, such as S. stellata, have a massive growth form (Leão et al. 2003), that is also associated with a higher thermal stress tolerance (Loya et al. 2001, Schlöder \& D'Croz 2004) in comparison to branching corals (Brown et al. 1990, Glynn 1996, Smith et al. 2014). These traits of Brazilian coral may drive the higher resistance during thermal stress events registered so far, especially for $S$. stellata at Rocas Atoll, due to its massive morphology, possible thermal tolerant symbiont diversity (Costa et al. 2008) inhabiting shallow and warm tide pools (Echeverria et al. 1997). In addition, Rocas Atoll is isolated from the mainland and is the most effective marine protected area in Brazil, lacking local stressors (Brandão et al. 2017) that could act in concert with global drivers that promote coral bleaching. On the other hand, Rocas Atoll is a shallow and non-turbid reef, therefore more susceptible to bleaching due to thermal stress than coastal ones (Glynn 1996, Takahashi et al. 2004).

This scenario may have started to change from 2019, when the incidence of severe MHW in some reefs, such as at Rocas Atoll, Abrolhos coral reefs and São Paulo rocky reefs, triggered the highest bleaching events registered so far in the Southwestern Atlantic (Banha et al. 2019, Duarte et al. 2020). Impacts of MHW on coral reefs have been reported in Australia (Le Nohaïc 

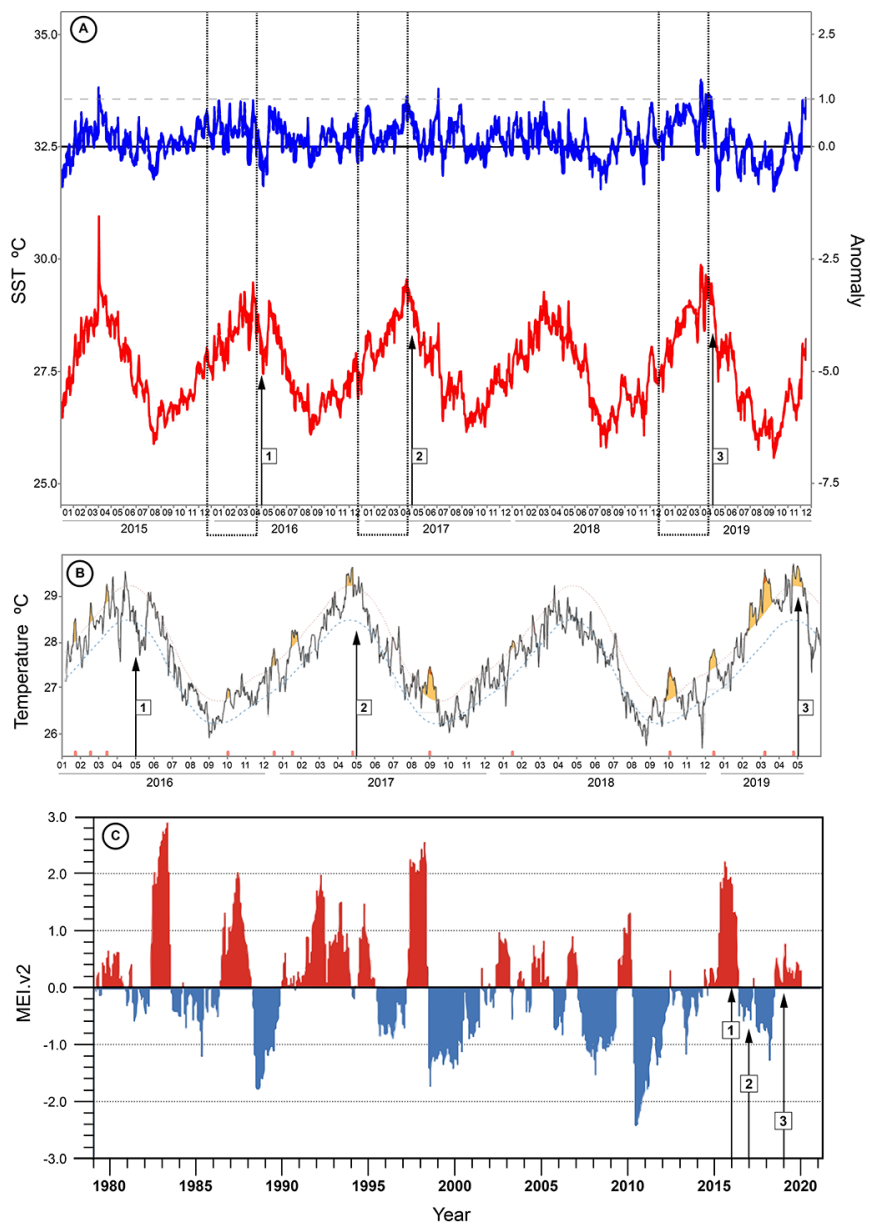

Figure 3. Temporal thermal series. A) Daily mean values of sea surface temperature (red line) and thermal anomaly (blue line) reported for Rocas Atoll. Numbers (1-3) within a small square indicate the sampling moment in each year and the big dashed square shows the four months prior to the survey, when thermal stresses were analyzed. The x-axis represents time, with monthly intervals, from January 2016 to June 2019 . The main y-axis represents the SST $\left({ }^{\circ} \mathrm{C}\right)$ and the secondary the anomaly $\left({ }^{\circ} \mathrm{C}\right)$. Data extracted from the satellite (AVHRR) and made available by NOAA (http://www.esrl.noaa.gov/psd/). B) Marine Heatwaves at Rocas Atoll, between 01/01/2016 and 05/31/2019. The red dotted line is the threshold value for each location for each day of the year and is defined based on the 90th percentile value. A thermal stress event that is at least five days or more above this threshold value represents a MHW (orange areas). The lightest orange areas represent moderate MHW, and the darkest strong events. The dashed blue line represents the climatological mean. Numbers (1-3) within a small square indicate the sampling moment in each year. The $\mathrm{x}$-axis represents time, with monthly intervals, and the y-axis represents the SST $\left({ }^{\circ} \mathrm{C}\right)$. Available at http://www.marineheatwaves.org/tracker.html. C) Multivariate ENSO indices (y-axis) from 1979 to 2020 (x-axis). El Niño (positive phase) in red; La Niña (negative phase) in blue. Numbers (1-3) within a small white square next to the arrows indicate the sampling years $(1=2016 ; 2=2017 ; 3=2019)$. Data source: (esrl.noaa.gov/psd/enso/mei)

et al. 2017, Clarke et al. 2019) and some Pacific islands, with different coral species being affected (Rubio-Portillo et al. 2016, Falter et al. 2016, Couch et al. 2017). Unlike large spatial and temporal scale ENSO events, MHW represents the most extreme and "rare" incidences of thermal stress relative to a seasonally dependent historical baseline (Hobday et al. 2016). However, similarly to ENSO, the duration and frequency of MHW has increased significantly since the early twentieth century (Oliver et al. 2018, Laufkötter et al. 2020). It is worth mentioning that the effects of MHW on coral reefs are distinct from how coral bleaching has been understood to date, resulting in an immediate heat-induced coral mortality, rapid dissolution of the coral skeleton, and loss of the three-dimensional reef structure (Leggat et al. 2019).

This work highlights the need to re-think our understanding of coral bleaching events in Southwestern Atlantic reefs, its drivers and the immediate impact on corals, especially in Brazilian reefs whose responses to thermal stress are still poorly understood (Mies et al. 2020). Maintaining time series for monitoring coral population parameters and environmental drivers is crucial for understanding coral bleaching phenomena in the Southwestern Atlantic and better addressing the coral reef crisis. Rocas Atoll is one of the most effective marine protected areas in Brazil, with minimal local anthropogenic impacts and may be used as a natural model system for evaluating global impacts on its reef community. Indeed, a better understanding of what are the main drivers of coral bleaching in Southwestern Atlantic can be useful to improve predictions and anticipate impacts on Brazilian reefs related to global change.

\section{Acknowledgments}

This work was supported by the research programme "Programa de Monitoramento de Longa Duração das Comunidades Recifais de Ilhas Oceânicas - PELD ILOC" (CNPq 441241/2016-6). We thank ICMBio for permit (\#58324-4), Jarian Dantas, Maurizélia de Brito Silva and SOS Mata Atlântica for logistical support; Davi Candido for help with sea surface temperature and thermal anomaly extraction; Regina Rodrigues and Natasha Costa for fruitful discussions about MHW and ENSO effects in the Atlantic Ocean. We thank two anonymous referees who provided valuable comments and Tito Lotufo who made a final careful review. JPQ received a post-doctoral fellowship from FAPESP (2018/21380-0). TLG received a Msc fellowship from CAPES (88882.438549/2019-01).

\section{Author Contributions}

Tainá Gaspar: substantial contribution to the concept and design of the study; contribution to the data collection; contribution to the data analysis and interpretation; contribution to manuscript preparation.

Juan Quimbayo: substantial contribution to the concept and design of the study; contribution to the data collection; contribution to the data analysis and interpretation; contribution to manuscript preparation.

Renan Ozekoski: substantial contribution to the concept and design of the study; contribution to the data collection; contribution to manuscript preparation.

Lucas Nunes: substantial contribution to the concept and design of the study; contribution to the data collection; contribution to manuscript preparation.

Amana G. Garrido: contribution to the data collection; contribution to manuscript preparation.

Thiago C. Mendes: contribution to the data collection; contribution to manuscript preparation.

Anaide W. Aued: substantial contribution to the concept and design of the study; contribution to manuscript preparation; contribution to critical revision, adding intellectual content.

Bárbara Segal: substantial contribution to the concept and design of the study; contribution to manuscript preparation; contribution to critical revision, adding intellectual content.

\section{Conflicts of Interest}

The authors declare that they have no conflict of interest related to the publication of this manuscript. 


\section{References}

BAKER, A. C., GLYNN, P. W., RIEGL, B., 2008. Climate change and coral reef bleaching: An ecological assessment of long-term impacts, recovery trends and future outlook. Estuar. Coast Mar Sci, v.80, n. 4, p.435-471.

BANHA, T. N. S., CAPEL, K. C. C., KITAHARA, M. V., FRANCINIFILHO, R. B., FRANCINI, C. L. B., SUMIDA, P.Y. G., \& MIES, M. 2019. Low coral mortality during the most intense bleaching event ever recorded in subtropical Southwestern Atlantic reefs. Coral Reefs, p.1-7.

BERKELMANS, R., DE'ATH, G., KININMONTH, S., \& SKIRVING, W. J. 2004. A comparison of the 1998 and 2002 coral bleaching events on the Great Barrier Reef: spatial correlation, patterns, and predictions. Coral Reefs, v.23, n. 1, p.74-83.

BOPP, L., RESPLANDY, L., ORR, J. C., DONEY, S. C., DUNNE, J. P., GEHLEN, M., HALLORAN, P., HEINZE, C., ILYINA, T., SÉFÉRIAN, R., TJIPUTRA, J., \& VICHI, M. 2013. Multiple stressors of ocean ecosystems in the 21st century: projections with CMIP5 models, Biogeosciences, v.10, p.6225-6245.

BRANDÃO, C., MALTA, A., \& SCHIAVETTI, A. 2017. Temporal assessment of the management effectiveness of reef environments: The role of marine protected areas in Brazil. Ocean. Coast. Manage., v. 142 , p. $111-121$.

BROWN, B. E. 1990. Damage and recovery of coral reefs affected by El Niño related seawater warming in the Thousand Islands, Indonesia. Coral Reefs, v.8, n. 4, p.163-170.

CHEUNG, W. W., \& FRÖLICHER, T. L. 2020. Marine heatwaves exacerbate climate change impacts for fisheries in the northeast Pacific. Sci. Rep-UK, v.10, n. 1, p.1-10.

ClARKE, H., D'OliVO, J. P., CONDE, M., EVANS, R. D., \& MCCULLOCH, M. T. 2019. Coral Records of Variable Stress Impacts and Possible Acclimatization to Recent Marine Heat Wave Events on the Northwest Shelf of Australia. Paleoceanogr. Paleoclimatol., v.34, n. 11, p.1672-1688.

COSTA, C. F., COUTINHO, C. S., SASSI, R., \& BRITO, L. A. C. 2004. Microsymbionts of Siderastraea stellata (Cnidaria, Scleractinia) in coastal reefs of Cabo Branco, State of Paraíba, northeastern Brazil. Trop. Oceanogr, v. 32(2), p. 173-181.

COSTA, C. F., SASSI, R., \& GORLACH-LIRA, K. 2008. Zooxanthellae genotypes in the coral Siderastrea stellata from coastal reefs in northeastern Brazil. J. Exp. Mar. Biol. Ecol., v.367, n. 2, p.149-152.

COUCH, C. S., BURNS, J. H., LIU, G., STEWARD, K., GUTLAY, T. N., KENYON, J., EAKIN, C. M., KOSAKI, R. K. 2017. Mass coral bleaching due to unprecedented marine heatwave in Papahānaumokuākea Marine National Monument (Northwestern Hawaiian Islands). PloS One, v.12, n. 9, p.e0185121.

DIAS, T. L. P., \& GONDIM, A. I. 2016. Bleaching in scleractinians, hydrocorals, and octocorals during thermal stress in a northeastern Brazilian reef. Mar. Biodivers., v.46, n. 1, p.303-307.

DONNER, S. D., RICKBEIL, G. J., \& HERON, S. F. 2017. A new, highresolution global mass coral bleaching database. PloS One, v.12, n. 4, p.e0175490.

DUARTE, G. A., VILLELA, H. D., DEOCLECIANO, M., SILVA, D., BARNO, A., CARDOSO, P. M., VILELA, C. L. S., MESSIAS, C. S. M. A., CHACON, M. A., SANTORO, E. P., OLMEDO, D. B., SZPILMAN M., ROCHA, L. A., SWEET, M., PEIXOTO, R. S., 2020. Heat waves are a major threat to turbid coral reefs in Brazil. Front. Mar. Sci., v.7, p.179.
EAKIN, C. M., LIU, G., GOMEZ, A. M., DE LA COUR, J. L., HERON, S. F., SKIRVING, W. J., GEIGER, E. F., MARSH, B. L., TIRAK, K. V., STRONG, A. E. 2017. Ding, dong, the witch is dead (?)-three years of global coral bleaching 2014-2017. Reef Encounter, v.32, p.33-38.

EAKIN, C. M., SWEATMAN, H. P., \& BRAINARD, R. E. 2019. The 2014-2017 global-scale coral bleaching event: insights and impacts. Coral Reefs, v.38, n. 4, p.539-545.

ECHEVERRÍA, C. A., PIRES, D. O., MEDEIROS, M. S., \& CASTRO, C. B. 1997. Cnidarians of the Atol das Rocas, Brazil. In Proc. 8th Int. Coral Reef Symp., Balboa, v.1, p.443-446.

FALTER, J., ZHANG, Z., LOWE, R., FOSTER, T., \& MCCULLOCH, M. T. 2016. Climate-driven variations in thermal forcing across a nearshore reef system during a marine heat wave and its potential impact on coral calcification. AGUOS, v.2016, p.AH13A-06.

FERREIRA, B. P., MAIDA, M., CASTRO, C. B., PIRES, D. O., DAMICO, T. M., PRATES, A. P., \& MARX, D. 2006. The status of coral reefs in Brazil. In: Proc. 10th Intern. Coral Reef. Symp.p.1011-1015.

FERREIRA, B. P., COSTA, M. B. S. F., COXEY, M. S., GASPAR, A. L. B., VELEDA, D., ARAÚJO, M. 2013. The effects of sea surface temperature anomalies on oceanic coral reef systems in the southwestern tropical Atlantic. Coral Reefs, v.32, n. 2, p.441-454.

FORDYCE, A. J., AINSWORTH, T. D., HERON, S. F., LEGGAT, W. 2019. Marine heatwave hotspots in coral reef environments: physical drivers, ecophysiological outcomes and impact upon structural complexity. Front. Mar. Sci, v.6, p.498.

GARCIA, N. A. C., CAMPOS, J. E., MUSI, J. L. T., FORSMAN, Z. H., MUNOZ, J. L. M., REYES, A. M., \& GONZÁLEZ, J. E. A. 2017. Comparative molecular and morphological variation analysis of Siderastrea (Anthozoa, Scleractinia) reveals the presence of Siderastrea stellata in the Gulf of Mexico. Biol. Bull., 232(1), 58-70.

GLEASON, D. F. 1993. Differential effects of ultraviolet radiation on green and brown morphs of the Caribbean coral Porites astreoides. Limnol. Oceanogr., v.38, n. 7, p.1452-1463.

GLYNN, P. W. 1993. Coral reef bleaching: ecological perspectives. Coral Reefs, v.12, n. 1, p.1-17.

GLYNN, P. W. 1996. Coral reef bleaching: facts, hypotheses and implications. Glob. Change. Biol., v.2, n. 6, p.495-509.

GRAHAM, N. A. J., \& NASH, K. L. 2013. The importance of structural complexity in coral reef ecosystems. Coral Reefs, v.32, n. 2, p.315-326.

HOBDAY, A. J., ALEXANDER, L. V., PERKINS, S. E., SMALE, D. A., STRAUB, S. C., OLIVER, E. C., BENTHUYSEN, J. A., BURROWS, M. T., DONAT, M. G., FENG, M., HOLBROOK, N. J., MOORE, p.J., SCANNELL, H. A., GUPTA, A. S., WERNBERG, T. 2016. A hierarchical approach to defining marine heatwaves. Progr. Oceanogr., v.141, p.227-238.

HOEGH-GULDBERG, O. 1999. Climate change, coral bleaching and the future of the world's coral reefs. Mar. Freshwater Res., v.50, n. 8, p.839-866.

HUGHES, T. P., BAIRD, A. H., BELLWOOD, D. R., CARD, M., CONNOLLY, S. R., FOLKE, C., GROSBERG, R., HOEGHGULDBERG, O., JACKSON, J. B. C., KLEYPAS, J., LOUGH, J. M., MARSHALL, P., NYSTRÖM, M., PALUMBI, S. R., PANDOLFI, J. M., ROSEN, B., ROUGHGARDEN, J. 2003. Climate change, human impacts, and the resilience of coral reefs. Science, v.301, n. 5635, p.929-933. 
HUGHES, T. P., KERRY, J., ÁlVAREZ-NORIEGA, M., ÁLVAREZROMERO, J., ANDERSON, K., BAIRD, A., BABCOCK, R., BEGER, M., BELLWOOD, D., BERKELMANS, R., BRIDGE, T., BUTLER, I., BYRNE, M,., CANTIN, N., COMEAU, S., CONNOLLY, S., CUMMING, G., DALTON, S., DIAZ-PULIDO, G., EAKIN, C. M., FIGUEIRA, W., GILMOUR, J., HARRISON, H., HERON, S., HOEY, A. S., HOBBS, J-P., HOOGENBOOM, M., KENNEDY, E., KUO, C-Y., LOUGH, J., LOWE, R., LIU, G., MCCULLOCH H. M., MCWILLIAM, M., PANDOLFI, J., PEARS, R., PRATCHETT, M., SCHOEPF, V., SIMPSON, T., SKIRVING, W., SOMMER, B., TORDA, G., WACHENFELD, D., WILLIS, B., WILSON, S. 2017. Global warming and recurrent mass bleaching of corals. Nature, v.543, n. 7645, p.373-377.

HUGHES, T. P., ANDERSON K. D., CONNOLLY, S. R., HERON, S. F., KERRY, J. T., LOUGH, J. M., BAIRD, A. H., BAUM, J. K., BERUMEN, M. L., BRIDGE, T. C., CLAAR, D. C., EAKIN, C. M., GILMOUR, J. P., GRAHAM, N. A. J., HARRISON, H., HOBBS, J-P.A., HOEY, A. S., HOOGENBOOM, M., LOWE, R. J., MCCULLOCH, M. T., PANDOLFI, J. M., PRATCHETT, M., SCHOEPF, V., TORDA, G., WILSON, S. K. 2018. Spatial and temporal patterns of mass bleaching of corals in the Anthropocene. Science v.359, n. 6371, p.80-83.

JONES, T., PARRISH, J. K., PETERSON, W. T., BJORKSTEDT, E. P., BOND, N. A., BALLANCE, L. T., BOWES, V., HIPFNER, M., BURGESS, H. K., DOLLIVER, J. E., LINDQUIST, K., LINDSEY, J., NEVINS, H. M., ROBERTSON, R. R., ROLETTO, J., WILSON, L., JOYCE, T., HARVEY, J. 2018. Massive mortality of a planktivorous seabird in response to a marine heatwave. Geophys. Res. Lett., v.45, n. 7, p.3193-3202.

KELMO, F., \& ATTRILL, M. J. 2013. Severe impact and subsequent recovery of a coral assemblage following the 1997-8 El Niño event: a 17-year study from Bahia, Brazil. PloS One, v.8, n. 5, p.e65073.

KIKUCHI, R. D., \& LEÃO, Z. M. A. N. 1997. Rocas (Southwestern Equatorial Atlantic, Brazil): an atoll built primarily by coralline algae. In Proc 8th Int Coral Reef Symp, v.1, p.731-736.

LAUFKÖTTER, C., ZSCHEISCHLER, J., FRÖLICHER, T. L. 2020. High-impact marine heatwaves attributable to human-induced global warming. Science, v. 369, n. 6511, p. 1621-1625.

LE NOHAÏC, M., ROSS, C. L., CORNWALL, C. E., COMEAU, S., LOWE, R., MCCULLOCH, M. T., \& SCHOEPF. 2017. Marine heatwave causes unprecedented regional mass bleaching of thermally resistant corals in northwestern Australia. Sci. Rep., v.7, n. 1, p.1-11.

LEÃO, Z. M., KIKUCHI, R. K., \& TESTA. 2003. Corals and coral reefs of Brazil. In Latin American coral reefs. Else. Sci., p.9-52.

LEÃO, Z. M. A. N., MINERVINO-NETO, A., FERREIRA, B. P., FEITOSA, C. V., SAMPAIO, C. L., SAMPAIO, C. L., ... \& LEITE, T. S. 2015. Monitoramento dos recifes e ecossistemas coralinos. Protocolos de campo para o monitoramento de habitats bentônicos costeiros. In: Turra A, Denadai MR (org) Protocolos para o Monitoramento de Habitats Bentônicos Costeiros: Rede de Monitoramento de Habitats Bentônicos Costeiros - ReBentos. São Paulo, Brazil, pp 156-179.

LEÃO, Z. M., KIKUCHI, R. K., FERREIRA, B. P., NEVES, E. G., SOVIERZOSKI, H. H., OLIVEIRA, M. D., MAIDA, M., CORREIA, M. D., JOHNSSON, R. 2016. Brazilian coral reefs in a period of global change: A synthesis. Braz. J. Oceanogr., v.64, n. SPE2, p.97-116.
LEGGAT, W. P., CAMP, E. F., SUGGETT, D. J., HERON, S. F., FORDYCE, A. J., GARDNER, S., DEAKIN, L., TURNER, M., BEECHING, L. J., KUZHIUMPARAMBIL, U., EAKIN, C. M., AINSWORTH, T. D., 2019. Rapid coral decay is associated with marine heatwave mortality events on reefs. Curr. Biol., v.29, n. 16, p.2723-2730.

LESSER, M. P. 2011. Coral bleaching: causes and mechanisms. In: Coral reefs: an ecosystem in transition. Springer, Dordrecht, p. 405-419.

LISBOA, D. S., KIKUCHI, R. K. P., \& LEÃO, Z. M. 2018. El Nino, sea surface temperature anomaly and coral bleaching in the South Atlantic: A chain of events modeled with a Bayesian approach. J. Geophys. Res.: Oceans, v.123, n. 4, p.2554-2569.

LONGO, G. O., MORAIS, R. A., MARTINS, C. D. L., MENDES, T. C., AUED, A. W., CÂNDIDO, D. V., OLIVEIRA, J. C., NUNES, L. T., FOUNTOURA, L SISSINI, M. N., TESCHIMA, M. M., SILVA, M. B., RAMLOV, F., GOUVEA, L. P., FERREIRA, C. E. L., SEGAL, B., HORTA, p.A., FLOETER, S. R. 2015. Betweenhabitat variation of benthic cover, reef fish assemblage and feeding pressure on the benthos at the only atoll in South Atlantic: Rocas Atoll, NE Brazil. PLoS One, v.10, n. 6, p.e0127176.

LOYA, Y., SAKAI, K., YAMAZATO, K., NAKANO, Y., SAMBALI, H., \& VAN WOESIK, R. 2001. Coral bleaching: the winners and the losers. Ecol. Lett., v.4, n. 2, p.122-131.

MARSHALL, p.A., \& BAIRD, A. H. 2000. Bleaching of corals on the Great Barrier Reef: differential susceptibilities among taxa. Coral Reefs, v.19, n. 2, p.155-163.

MIES, M., FRANCINI-FILHO, R.B., ZILBERBERG, C., GARRIDO, A.G., LONGO, G.O., LAURENTINO, E., GÜTH, A.Z., SUMIDA, P.Y. AND BANHA, T.N., 2020. South Atlantic coral reefs are major global warming refugia and less susceptible to bleaching. Front. Mar. Sci., v.7, p.514.

MIGOTTO, A. E. 1997. Anthozoan bleaching on the southeastern coast of Brazil in the summer of 1994. In: Proc. 6th Int. Conf. Coelenterate Biol.. p.329-335.

MIRANDA, R. J., CRUZ, I. C., \& LEÃO, Z. M. 2013. Coral bleaching in the Caramuanas reef (Todos os Santos Bay, Brazil) during the 2010 El Niño event. Lat. Am. J. Aquat. Res., v.41, n. 2, p.351-360.

MONTEIRO, J. G., COSTA, C. F., GORLACH-LIRA, K., FITT, W. K., STEFANNI, S. S., SASSI, R., SANTOS, R. S., \& LAJEUNESSE, T. C. 2013. Ecological and biogeographic implications of Siderastrea symbiotic relationship with Symbiodinium sp.C46 in Sal Island (Cape Verde, East Atlantic Ocean). Mar. Biodivers., v.43, n. 4, p.261-272.

MUSCATINE, L., FALKOWSKI, p.G., PORTER, J. W., \& DUBINSKY, Z. 1984. Fate of photosynthetic fixed carbon in light-and shade-adapted colonies of the symbiotic coral Stylophora pistillata. p.R. Soc. Lond.. B. Bio. v.222, n.1227, p.181-202.

OLIVER, J. K., BERKELMANS, R., \& EAKIN, C. M. 2009. Coral bleaching in space and time. In: Coral bleaching. Springer, Berlin, Heidelberg, p.21-39.

OLIVER, E. C. J., DONAT, M. G., BURROWS, M. T., MOORE, P.J., SMALE, D. A., ALEXANDER, L. V., BENTHUYSEN, J. A., FENG, M., GUPTA, A. S., HOBDAY, A. J., HOLBROOK, N. J., PERKINS-KIRKPATRICK, S. E., SCANNELL, H. A., STRAUB, S. C., WERNBERG, T. 2018. Longer and more frequent marine heatwaves over the past century. Nat. Commun., v. 9, n. 1, p. 1-12.

PERRY, C. T., MURPHY, G. N., KENCH, P.S., SMITHERS, S. G., EDINGER, E. N., STENECK, R. S., \& MUMBY, P. J. 2013. Caribbeanwide decline in carbonate production threatens coral reef growth. Nat. Commun., v.4, n.1, p.1-7. 
R CORE TEAM. 2018. R: A language and environment for statistical computing. R Foundation for Statistical Computing, Vienna, Austria.

RODRIGUES, R. R., TASCHETTO, A. S., GUPTA, A. S., \& FOLTZ, G. R. 2019. Common cause for severe droughts in South America and marine heatwaves in the South Atlantic. Nat. Geosc., v.12, n.8, p.620-626.

RUBIO-PORTILLO, E., IZQUIERDO-MUÑOZ, A., GAGO, J. F., ROSSELLÓ-MORA, R., ANTÓN, J., \& RAMOS-ESPLÁ, A. A. 2016. Effects of the 2015 heat wave on benthic invertebrates in the Tabarca Marine Protected Area (southeast Spain). Mar. Environ. Res., v.122, p.135-142.

SCHLEGEL, R. W. 2018. Marine Heatwave Tracker: The app to see when and where marine heatwaves are happening around the world. Available at: Tracker - Marine heatwaves (accessed December 1, 2019).

SCHLÖDER, C. \& D'CROZ, L. 2004. Responses of massive and branching coral species to the combined effects of water temperature and nitrate enrichment. J. Exp.Mar. Biol. Ecol., v.313, n.2, p.255-268.

SKIRVING, W. J., HERON, S. F., MARSH, B. L., LIU, G., DE LA COUR, J. L., GEIGER, E. F., \& EAKIN, C. M. 2019. The relentless march of mass coral bleaching: a global perspective of changing heat stress. Coral Reefs, v.38, n.4, p,547-557.

SMALE, D. A., WERNBERG, T., OLIVER, E. C., THOMSEN, M., HARVEY, B. P., STRAUB, S. C., BURROWS, M. T., ALEXANDER, L. V., BENTHUYSEN, J. A., DONAT, M. G., FENG, M., HOBDAY, A. J., HOLBROOK, N., PERKINS-KIRKPATRICK, S. E., SCANELL, H. A., GUPTA, A. S., PAYNE, B. L., MOORE, P.J. 2019. Marine heatwaves threaten global biodiversity and the provision of ecosystem services. Nat. Clim. Change, v.9, n.4, p.306-312.

SMITH, T. B., GLYNN, P.W., MATÉ, J. L., TOTH, L. T., \& GYORY, J. 2014. A depth refugium from catastrophic coral bleaching prevents regional extinction. Ecology, v.95, n.6, p.1663-1673.

SOARES, M. 2018 Climate change and regional human pressures as challenges for management in oceanic islands, South Atlantic. Mar. Pollut. Bull, v. 131, p. 347-355.
SOARES, M., TEIXEIRA, C. E. P., FERREIRA, S. M. C., GURGEL, A. L. A. R., PAIVA, B. P., MENEZES, M. O. B., DAVIS, M., TAVARES, T. C. L. 2019. Thermal stress and tropical reefs: mass coral bleaching in a stable temperature environment?. Mar. Biodivers., v.49, n.6, p.2921-2929.

SWAIN, T. D., CHANDLER, J., BACKMAN, V., \& MARCELINO, L. 2017. Consensus thermotolerance ranking for 110 Symbiodinium phylotypes: an exemplar utilization of a novel iterative partial-rank aggregation tool with broad application potential. Funct. Ecol., v. 31(1), p.172-183.

TAKAHASHI, S., NAKAMURA, T., SAKAMIZU, M., WOESIK, R. V., \& YAMASAKI, H. 2004. Repair machinery of symbiotic photosynthesis as the primary target of heat stress for reef-building corals. Plant. Cell. Physiol., v. 45(2), p. 251-255.

TEIXEIRA, C. D., LEITÃO, R. L., RIBEIRO, F. V., MORAES, F. C., NEVES, L. M., BASTOS, A. C., PEREIRA-FILHO, G. H., KAMPEL, M., SALOMON, P.S., SÁ, J. A., FALSARELLA, L. N., AMARIO, M., ABIERI, M. L., PEREIRA, R. C., AMADO-FILHO, G. M., MOURA, R. L. 2019. Sustained mass coral bleaching (2016-2017) in Brazilian turbid-zone reefs: taxonomic, cross-shelf and habitat-related trends. Coral Reefs, v.38, n.4, p.801-813.

VAUGHAN, T. 1914. Sketch of the geologic history of the Florida coral reef tract and comparisons with other coral reef areas. J. Wash. Acad. Sci., v.4, n.2, p.26-34.

WOLTER, K., \& TIMLIN, M. S. 1993. Monitoring ENSO in COADS with a Seasonally Adjusted Principal. In Proc. of the 17th Climate Diagnostics Workshop, Norman, OK, NOAA/NMC/CAC, NSSL, Oklahoma Clim. Survey, CIMMS and the School of Meteor., Univ. of Oklahoma, 52 (Vol. 57).

Received: $10 / 09 / 2020$

Revised: 05/03/2021

Accepted: 08/03/2021

Published online: 12/04/2021 